\title{
Studies on Biometric Parameters of Cashew in Bhubaneswer Condition
}

\author{
Anindita Roy ${ }^{1}$, D.K. Dora ${ }^{1}$, K. Sethi ${ }^{1}$, S. Sahu ${ }^{2}$, D.K. Dash ${ }^{1}$ and A. Parida ${ }^{3}$ \\ ${ }^{1}$ Department of Fruit Science and Horticulture Technology, ${ }^{2}$ Department of Plant Breeding \\ and Genetics, ${ }^{3}$ Department of Agricultural Statistics, University of Agriculture and \\ Technology, Bhubaneswar 751003, Odisha, India \\ *Corresponding author
}

\section{A B S T R A C T}

\begin{tabular}{|c|c|}
\hline & \multirow{7}{*}{$\begin{array}{l}\text { An investigation was laid out in cashew research station under AICRP on cashew } \\
\text { Ranasinghapur, Bhubaneswar, Khurda during the year } 2015-2017 \text {, to study the variability } \\
\text { in biometric parameters of thirty land races of cashew such as plant height, plant girth, } \\
\text { canopy spread in east -west and north-south direction, canopy area and Yield in } \\
\text { Bhubaneswar condition. It was found that the plant height varied from } 3.47 \mathrm{~m} \text { in RP-6 to } \\
\text { maximum of } 7 \mathrm{~m} \text { in Tapanga, The girth of plant was maximum in RP-3(95.40) } \mathrm{cm} \text { and } \\
\text { significantly superior to all treatments and minimum was recorded in RP-6 is }(46.50 \mathrm{~cm}) \text {, } \\
\text { The canopy spread was measured in East-West and North-South direction and significant } \\
\text { variation was observed among the treatments, The canopy spread was maximum in East- } \\
\text { West and North-South direction in Dutiya Nayapalli }(9.5 \mathrm{~m}) \text { and minimum in Dhauli } \\
\text { (4.5m). The canopy area of Dutiya Nayapalli was recorded } 70.73 \text { per } \mathrm{m}^{2} \text { and minimum was } \\
\left.\text { recorded in Dhauli ( } 18.56 \text { per } \mathrm{m}^{2}\right) \text { and the highest yield was recorded (15.7kg in BH-85 } \\
\text { and minimum yield recorded was } 1.4 \mathrm{~kg} \text { in RP-3. BH-5 was found significantly superior to } \\
\text { all other genotypes. Hence Production of elite genotypes is one of the main mandates of } \\
\text { crop improvement programme and potential promising cashew genotypes are } \\
\text { recommended for cultivation. }\end{array}$} \\
\hline Keywords & \\
\hline $\begin{array}{l}\text { Biom } \\
\text { paran } \\
\text { cano } \\
\text { girth, } \\
\text { and }\end{array}$ & \\
\hline Article Info & \\
\hline & \\
\hline & \\
\hline & \\
\hline
\end{tabular}

\section{Introduction}

Cashew is a versatile tree nut with multifarious uses. In fact it is a precious gift of nature to mankind. It is considered as 'Gold Mine' of wastelands as it requires low inputs for production from its humble beginning as a crop intended to check soil erosion, cashew has emerged as a major foreign exchange earner next only to tea and coffee. As a whole, cashew nuts are becoming established as a food item that can protect human beings against major diseases including heart diseases, diabetics, cancer etc. with its rare combination of fats, carbohydrates and protein. Now, the total production of cashew in the country is $7.79 \mathrm{M}$ tones from 1035 thousand hectare area "(Horticultural statistics at a glance. 2016-17)". Most of the area under cashew is in the East-Coast and West-Coast regions of the country. In Odisha, productivity of cashew is about $513 \mathrm{~kg}$ / ha from an area of 183.3 thousand hectare (Horticultural statistics at a glance, 2016-17). Higher productivity of cashew is under Maharashtra and due to development of plantation by using high 
yielding clone, better adaptation of agro techniques, better soil fertility condition etc. On the other hand, in Odisha most of the old cashew plantations are grown in unfertile soils with low yielding seedling plants and lack of proper production technology etc.

The major constraints of low production of cashew are due to inferior genetic stock coupled with poor management. The achievements on crop improvement were not focused. The success of plant breeding depends on significant level of genetic variability in the original population followed by an efficient selection method for fixation of desirable genetic combinations. The present investigation was carried out to critically study the variability of thirty land races basing on biometric parameters.

\section{Materials and Methods}

\section{Experimental site}

An experiment was conducted at All India Coordinate Research Project on cashew O.U.A.T., Bhubaneswar, in randomized block design with two replication and thirty treatments at the age of 16 years of plantation. It is situated at a latitude of $20^{\circ} 15^{\prime} \mathrm{N}$ and longitude of $85^{\circ} 52^{\prime} \mathrm{E}$ and altitude of 25.5 meters above the mean sea level. The site is 70 $\mathrm{km}$ away from the Bay of Bengal and falls under the East coastal plains and Hills zone of the humid tropics of India. The texture of soil is sandy loam Sand (81.2\%),Silt (1.2\%), Clay $(17.6 \%)$, Available water holding capacity (6.9 \%), Soil pH of 5.1, EC( $\left(\mathrm{dsm}^{-1}\right)$ 0.02, available nitrogen $(88 \mathrm{~kg} / \mathrm{ha})$, available $\mathrm{P}_{2} \mathrm{O}_{5}$ (28.1kg/ha), available $\mathrm{K}_{2} \mathrm{O}(80.2 \mathrm{~kg} / \mathrm{ha})$.

\section{Observations on biometric parameters}

Observations on biometric parameters were recorded, as per the standard descriptors of cashew (IBPGR, 1986; Swamy et al., 1998) for two seasons.
As per the descriptors of cashew, considering the overall nature of tree growth, cashew genotypes were categorized in to "upright and compact' (trunk erect with more number of erect branches), "upright and open" (trunk erect and usually with sparse more of open branches) and "spreading" (branches close to ground spreading horizontally) tree habit. The height of the tree was measured vertically from the ground to the tip of the tree in meters and expressed in meters. The circumference of the tree trunk was measured at $30 \mathrm{~cm}$ above from the base and expressed as tree girth in centimeters. The diametric length of the ground space occupied by the tree was measured in two directions and the canopy spread was recorded in meters as "NorthSouth Spread" and East-West Spread" for all genotypes.

\section{Results and Discussion}

It is revealed from the experiment that all the biometric parameter witnessed a significant variation in the pooled data.

\section{Plant height}

The height of plant during course of investigation was found significant in variation from the pooled data. It was observed that $\mathrm{T}_{19}$ (Tapanga) recorded the maximum plant height of $7 \mathrm{~m}$ and was significantly different from all other treatments, $\mathrm{T}_{27}, \mathrm{~T}_{28}$ and $\mathrm{T}_{7}$ were found statistically at par but significantly superior to rest of the treatments and also significantly superior to the checked genotypes BH-85, BBSR-1 and BH-6. The minimum plant height was recorded in $T_{26}$, RP-6 $(3.47 \mathrm{~m})$ followed by $\mathrm{T}_{25}, \mathrm{RP}-5(3.5 \mathrm{~m})$ and both were found statistically at par with significant superiority to all other land races.

\section{Girth}

A significant variation was observed in girth of plant. The girth of plant increased as age of 
plant increased and in both year of studies i.e. 2015-2016 and 2016-2017. A significant variation was observed among the landraces. The maximum girth was found in RP-3, $\mathrm{T}_{23}$ $(95.42 \mathrm{~cm})$ and was significantly superior to all other treatments followed by $\mathrm{T}_{19}$ Tapanga $(93.4 \mathrm{~cm}), \mathrm{T}_{13}$ Dutiya Nayapali $(92.1 \mathrm{~cm})$, BBSR-C-1 $\mathrm{T}_{27}(90.45 \mathrm{~cm})$ and the minimum plant height was recorded in RP-6 $(46.5 \mathrm{~cm})$ and was found statistically different from all other treatment and the checked genotype BBSR-1 $\mathrm{T}_{1}$ recorded girth of $66.02 \mathrm{~cm}$.

\section{Canopy spread of plant}

The spread of plant in both direction east-west to north-south was found significantly different in both years of studies. It was observed that the spread of plant increased with advancement of age from the pooled date, it was found that $T_{13}$ Dutiya Nayapali recorded maximum spread of $9.5 \mathrm{~m}^{2}$ and was found statistically different from all other treatments but at par with BBSR-C-2 (9.2) $\mathrm{m}^{2}$ $\mathrm{T}_{28}$ and $\mathrm{T}_{28}$ was found statistically at par with $\mathrm{T}_{3}$ Kalyanpur bold nut $\left(8.95 \mathrm{~m}^{2}\right)$ it was also recorded that $T_{3}, T_{15}, T_{11}, T_{23}$ were found at par but statistically different from all other treatments. Minimum spread was recorded in Dhauli $\mathrm{T}_{6}\left(4.5 \mathrm{~m}^{2}\right)$ and was found statistically par with $\mathrm{T}_{26}$ (RP-6) $4.7 \mathrm{~m}^{2}$ and was significantly different from all other treatments.

The spread of plant in North-South direction was found statistically significant and maximum was recorded in $\mathrm{T}_{13}$ Dutiya Nayapali $\left(9.35 \mathrm{~m}^{2}\right)$ and it was found significantly different from all other treatments and Minimum spread was recorded in $\mathrm{T}_{6}$ Dhauli $\left(5.05 \mathrm{~m}^{2}\right)$ and was found significantly different from all other landraces. $\mathrm{T}_{19}, \mathrm{~T}_{1}$ and $\mathrm{T}_{22}$ were found statistically at par but significantly different from rest of the landraces.
The canopy area of different genotypes was found statistically significant, maximum area was recorded in $T_{13}$ Dutiya Nayapali (70.73 $\mathrm{m}^{2}$ ) and it was found significantly superior to all other genotypes followed by BBSR-C-2 $\mathrm{T}_{28}\left(64.31 \mathrm{~m}^{2}\right), \mathrm{T}_{11}$ Lahanga-1 $\left(63.03 \mathrm{~m}^{2}\right)$ and minimum was recorded in Dhauli $\mathrm{T}_{18}(18.56$ $\mathrm{m}^{2}$ ), it was found that $\mathrm{T}_{6}, \mathrm{~T}_{26}, \mathrm{~T}_{22}$ and $\mathrm{T}_{19}$ were found at par but different from all other treatments.

The nut yield per plant in both year of study was found significant. In year of 2015 to 2016, the highest yield was recorded $(15.7 \mathrm{~kg}$ in $\mathrm{BH}-$ 85 followed by BH-6 is $13.40 \mathrm{~kg}$ and minimum recorded is $1.4 \mathrm{~kg}$ in $\mathrm{RP}-3, \mathrm{BH}-5$ was found significantly superior to all other genotypes. The released variety BBSR-1 recorded $6.40 \mathrm{~kg}$ and $6.62 \mathrm{~kg}$ in both the year of studies among the land races, BBSR-C-1 recorded maximum yield of $9.27 \mathrm{~kg}$, followed by Dhauli i.e. $9.2 \mathrm{~kg}$, Lokipur-1 $9.0 \mathrm{~kg}$, in 2nd year that is 2016-2017. significant variation was observed among the land races and yield per plant varies from $1.80 \mathrm{~kg}$ in RP-3 to maximum yield of $14.22 \mathrm{~kg}$ in $\mathrm{BH}-85$, BH-85 and $\mathrm{BH}-6$ were found significantly at par but significantly superior to all of the treatments.

Similar findings were also observed by earlier workers, Tsakiris (1967) reported that under reasonable favorable conditions young trees may grow up at a rate of about $1 \mathrm{~m}$ per year, their canopy diameter increases by about 1.5 $2.0 \mathrm{~m}$ per year for the first 5 to 6 years, after which growth may slow down, Manoj et al., (1994) found that the height of tree varied from $3.95 \mathrm{~m}$ to $10.00 \mathrm{~m}$ among sixteen parents and from $4.75 \mathrm{~m}$ to $9.88 \mathrm{~m}$ among fifty six hybrids and the mean canopy spread was found to be varying from $7.06 \mathrm{~m}$ to $15.08 \mathrm{~m}$ in case of hybrids and from $8.68 \mathrm{~m}$ to $14.38 \mathrm{~m}$ in case of parents. Singh et al., (2010) found that Madakkathara-1 and VTH-30/4 were found superior in plant height and were also found superior for canopy spread (Table 1). 
Table.1 Studies on vegetative characters of cashew genotypes

\begin{tabular}{|c|c|c|c|c|c|c|c|}
\hline Treatments & Genotypes & Height(m) & Girth(cm) & $\begin{array}{c}\text { Canopy } \\
\text { spread E/W }\end{array}$ & $\begin{array}{l}\text { Canopy } \\
\text { spread N/S }\end{array}$ & $\begin{array}{c}\text { Canopy } \\
\text { spread/ } \mathbf{M}^{2}\end{array}$ & Yield(kg) \\
\hline$T_{1}$ & Bhubaneswar- 1 & 4.35 & 66.02 & 7.85 & 5.25 & 35.04 & 6.51 \\
\hline $\mathbf{T}_{2}$ & $\begin{array}{l}\text { Ranasinghapur Bold } \\
\text { Nut }\end{array}$ & 5.46 & 79.25 & 7.89 & 6.45 & 42.38 & 8.20 \\
\hline$T_{3}$ & Kalyanpur Bold Nut & 5.72 & 60.95 & 8.95 & 6.70 & 49.70 & 2.66 \\
\hline$T_{4}$ & Lokipur_1 & 5.35 & 74.05 & 7.48 & 7.05 & 48.12 & 10.00 \\
\hline$T_{5}$ & OS-5 & 4.60 & 78.30 & 7.95 & 7.55 & 41.18 & 10.20 \\
\hline$T_{6}$ & Dhauli & 3.85 & 55.25 & 4.50 & 4.60 & 18.56 & 4.65 \\
\hline $\mathbf{T}_{7}$ & OS -3 & 6.52 & 79.55 & 8.10 & 7.90 & 52.34 & 8.50 \\
\hline$T_{8}$ & Khurda_1 & 4.45 & 63.00 & 7.25 & 6.10 & 37.18 & 4.00 \\
\hline $\mathrm{T}_{9}$ & Selection-8 & 6.45 & 90.10 & 7.80 & 7.15 & 47.43 & 8.15 \\
\hline$T_{10}$ & Selection-36 & 5.77 & 79.70 & 6.25 & 7.30 & 40.48 & 9.50 \\
\hline $\mathrm{T}_{11}$ & Lahanga-1 & 5.67 & 62.85 & 8.82 & 8.65 & 63.02 & 7.42 \\
\hline$T_{12}$ & koraput Cluster & 5.77 & 81.75 & 8.30 & 6.70 & 48.00 & 7.68 \\
\hline$T_{13}$ & Dutiya nayapali & 5.80 & 92.10 & 9.50 & 8.90 & 70.73 & 6.20 \\
\hline $\mathrm{T}_{14}$ & S-19 & 5.15 & 76.60 & 7.80 & 7.10 & 50.47 & 7.50 \\
\hline $\mathrm{T}_{15}$ & S-20 & 5.25 & 68.45 & 8.87 & 6.50 & 49.26 & 3.87 \\
\hline$T_{16}$ & S-21 & 5.35 & 67.10 & 7.25 & 6.55 & 38.95 & 3.80 \\
\hline$T_{17}$ & S-24 & 4.82 & 74.05 & 6.05 & 5.60 & 28.96 & 5.30 \\
\hline$T_{18}$ & S-25 & 6.05 & 68.50 & 7.80 & 5.40 & 36.74 & 7.12 \\
\hline$T_{19}$ & Tapanga & 7.00 & 93.40 & 5.65 & 5.05 & 24.33 & 7.53 \\
\hline$T_{20}$ & Bhanjakusama & 5.25 & 89.85 & 6.90 & 7.12 & 40.37 & 7.61 \\
\hline$T_{21}$ & RP-1 & 5.30 & 70.30 & 5.15 & 5.65 & 24.76 & 4.97 \\
\hline$T_{22}$ & RP-2 & 5.27 & 76.95 & 5.20 & 5.10 & 22.56 & 5.07 \\
\hline$T_{23}$ & RP-3 & 6.20 & 95.42 & 8.75 & 7.85 & 55.97 & 1.60 \\
\hline$T_{24}$ & RP-4 & 6.22 & 85.30 & 7.50 & 7.05 & 43.04 & 3.23 \\
\hline$T_{25}$ & RP-5 & 3.50 & 54.00 & 6.42 & 6.75 & 36.09 & 4.14 \\
\hline$T_{26}$ & RP-6 & 3.47 & 46.50 & 4.70 & 5.30 & 20.80 & 4.80 \\
\hline $\mathbf{T}_{27}$ & BBSR C-1 & 6.65 & 90.45 & 7.90 & 8.30 & 53.98 & 10.27 \\
\hline$T_{28}$ & BBSR C-2 & 6.62 & 83.15 & 9.20 & 8.50 & 64.30 & 7.60 \\
\hline$T_{29}$ & BH-6 & 4.92 & 57.85 & 5.84 & 5.60 & 27.86 & 12.97 \\
\hline \multirow[t]{4}{*}{$T_{30}$} & BH-85 & 4.70 & 68.15 & 5.80 & 6.30 & 30.79 & 14.96 \\
\hline & $\mathrm{F}$ test $(5 \% \& 1 \%)$ & ** & ** & ** & ** & ** & ** \\
\hline & $\mathrm{SE}(\mathrm{m}) \pm$ & 0.04 & 0.38 & 0.09 & 0.075 & 2.07 & 0.7 \\
\hline & C.D (5\%) & 0.13 & 1.11 & 0.27 & 0.217 & 6.02 & 2.05 \\
\hline
\end{tabular}

Samal et al., (2006) observed growth behavior of 11 clonal types that and found highest plant height was of $7.53 \mathrm{~m}$ in Vengurla-2 and the lowest plant height was $2.64 \mathrm{~m}$ in Vridhachalam. Lakshmana et al
(2011) observed maximum stem girth of 78 $\mathrm{cm}$ in the variety NDR-2-1was found

followed by $1 / 40$ Palaparamba and Vengurla-1, while minimum stem girth of $55 \mathrm{~cm}$ was found in variety VRI-3. 
Jayaprakash et al., (1997) found that in North-South direction the maximum and minimum canopy spread was in $\mathrm{H}-1600$ $(188.20 \mathrm{~cm})$ and $\mathrm{H}$ 3-13 (120.57 cm). Maximum diameter of canopy $(6.1 \mathrm{~m})$ was recorded in 5/23 Coondapur in North-South direction and minimum $(3.2 \mathrm{~m})$ in $2 / 97$ Kottarakara and 1/11 Ullal. Similarly in the East-West direction maximum spread (4.5 m) was observed in 4/62 Alangudi and minimum $(2.5 \mathrm{~m})$ in $1 / 26$ Nileshwar. (Narayana Reddy et al., 1986). The nut yield was the most variable characters studied, with the number of nuts per tree showing the highest variation (Dela Cruz and Fletcher, 1996). Abdul Salam (2000) found that there was significant difference in nut yield between varieties during different years of harvest. Mohapatra et al., (2017) experimented in eleven genotypes and found BH-85 and BH-6 was superior to all other genotypes and recommended for better nut yield in sustainable manner. The findings of earlier workers provide ample support to present findings. The biometric parameters plays a important role in enhancing quality yield. Therefore Potential promising cashew genotypes with superior biometric parameters should be recommended for breeding programme in order to achieve better yield under Bhubaneswar conditions.

\section{References}

Abdul Salam. 2000. Performance of cashew (Anacardium Occidentale L.) Genotypes under Kerala conditions. $J$. Plantation Crops, 23(2):70-77.

Chandre gowda, M., Krishnappa, M., Narayana Reddy, M.A. and Thrumala R. 1989. Performance of certain cashew (Anacardium occidentale L.) selections under Chintamani conditions. The Cashew. April-June 78.

Dela. Cruz, F. and Fletcher, R.J. 1996.
Identification of superior cashew trees for Northern Australian conditions. Proceedings, Fourth Annual research Conference. The University of Queensland Gatton, October,pp.60.

Horticultural statistics at a glance. (201617). Ministery of Statistics and programme Implementation

IBPGR, 1986. Cashew Descriptor List International Bureau of Plant Genetic Resources, Rome.

Jayaprakash N., Muraleedharan, B., Latha, P. and Sujatha, K. 1997. Growth and quality analysis of different genotypes of cashew in northern kerala. Oct-Dec. 31-34.

Lakshmana, Chandrappa, H., Guruprasad, T.R. and Seetharamu, G.K. 2011. Evaluation of cashew varieties performance under coastal zone of Karnataka. The Cashew and Cocoa Journal. Jan-March. 12-15.

Manoj, P.S., George. and T.E, Krishnan, S. 1994. Correlation studies and path coefficient analysis in cashew (Anacardium occidentale L.) hybrids. The Cashew. 8(2):10-14.

Mohapatra, M., Dash, D. K., Tripathy, P., Sethi, K.., Dash, M. and DAS, A. K. 2017 Performance of some cashew (Anacardium occidentale L) selections for Nut Yield. International Journal of Farm Sciences 7(1): 40-43

Narayanareddy, M.A, Sivanandam, V.N, Gowda, M.C. and Siddaraju, M. 1986. Morphological and yield characteristics of cashew selections under chintamani conditions. Cashew Causerie. 8 (2): 3-5.

Swamy, K.R.M., Bhaskar Rao, E.V.V. and Bhat, M.G. 1998. Catalogue of minimum descriptors of cashew, Germplasm-II, National Research Centre for Cashew (ICAR), Puttur, Karnataka, India.

Samal, S., Lenka, P.C. and Rout, G.R. 
2006. Evaluation of cashew varieties under Bhubaneswar condition for major plant characters and nut yield. The Cashew. April-June: 8-13.

Singh, L.S., Medda, P.S., Bhattacharjee, H. and Satya, P. 2010. Performance of six genotypes of cashew (Anacardium occidentale L.) under teraiagroclimatic zone of West Bengal. Asian
Journal of Horticulture. 5(1):131-33. Tsakiris, A.1967. Cashew nut production in the Southern region of Tanzania II. An economic study of cashew nut production by peasant farmers at Lulindi: East African Agricultural and Forestry Journal (Kenya). 32 (4): 445449.

\section{How to cite this article:}

Anindita Roy, D.K. Dora, K. Sethi, S. Sahu, D.K. Dash and A. Parida. 2018. Studies on Biometric Parameters of Cashew in Bhubaneswer Condition. Int.J.Curr.Microbiol.App.Sci. 7(12): 365-370. doi: https://doi.org/10.20546/ijcmas.2018.712.045 